\title{
Effects of Nitrogen on Temporal and Spatial Patterns of Nitrate in Streams and Soil Solution of a Central Hardwood Forest
}

\author{
Frank S. Gilliam ${ }^{1}$ and Mary Beth Adams ${ }^{2}$ \\ ${ }^{1}$ Department of Biological Sciences, Marshall University, Huntington, WV 25755-2510, USA \\ ${ }^{2}$ Timber and Watershed Laboratory, USDA Forest Service, Parsons, WV 26287, USA
}

Correspondence should be addressed to Frank S. Gilliam, gilliam@marshall.edu

Received 11 January 2011; Accepted 7 February 2011

Academic Editors: D. Gerten and S. Loppi

Copyright (C) 2011 F. S. Gilliam and M. B. Adams. This is an open access article distributed under the Creative Commons Attribution License, which permits unrestricted use, distribution, and reproduction in any medium, provided the original work is properly cited.

This study examined changes in stream and soil water $\mathrm{NO}_{3}{ }^{-}$and their relationship to temporal and spatial patterns of $\mathrm{NO}_{3}{ }^{-}$ in soil solution of watersheds at the Fernow Experimental Forest, West Virginia. Following tenfold increases in stream $\mathrm{NO}_{3}{ }^{-}$ concentrations over a 13-year period (1969-1981) on untreated WS4, concentrations have declined through 2006. Following fourfold increases in stream $\mathrm{NO}_{3}{ }^{-}$on treatment WS3 from pretreatment levels to a 1998 maximum, concentrations have declined through 2006, despite additions of $\mathrm{N}$. Concentrations of soil water $\mathrm{NO}_{3}{ }^{-}$were consistently lower for WS4 compared to WS3. Data for soil water $\mathrm{NO}_{3}{ }^{-}$on WS3 versus WS4 followed patterns of net mineralization and nitrification for these watersheds. Nitrogen additions to WS3 decreased spatial heterogeneity of $\mathrm{N}$ processing, which was largest in the pretreatment year and decreased significantly to a minimum by 2000-2001. Concurrently, soil water $\mathrm{NO}_{3}{ }^{-}$increased on WS3 from $1.3 \mathrm{mg} \mathrm{NO}_{3}{ }^{-} \mathrm{N} \mathrm{L}^{-1}$ in pretreatment 1989 to a maximum of $6.4 \mathrm{mg} \mathrm{NO}_{3}{ }^{-}-\mathrm{N} \mathrm{L}^{-1}$ in 2001. Spatial heterogeneity in soil water $\mathrm{NO}_{3}{ }^{-}$on WS4 remained high during this period. Data suggest that temporal patterns of stream $\mathrm{NO}_{3}{ }^{-}$may be influenced by spatial heterogeneity of watershed processes which vary over time in response to $\mathrm{N}$ availability.

\section{Introduction}

The structure and function of terrestrial ecosystems are maintained by processes that vary temporally and spatially. Furthermore, these scales of variation-through time and over space-can be highly codependent. Thus, the degree to which an ecosystem process, for example, nitrification, varies spatially is not a static property; rather, that degree of spatial variability changes over time. To borrow from Cowles' [1] description of the nature of plant succession, a given ecosystem process can often be thought of as "variable approaching a variable rather than a constant." Recently, there has been an interest in temporal phenomena as pulses [2] and spatial phenomena as subsidies [3]. Anderson et al. [3] concluded that the synergistic effects of temporally and spatially variable resources help explain the complexities of food web structure. Rietkerk and van de Koppel [4] reviewed several studies demonstrating that spatial pattern of ecosystems innately varies over time, which they called "spatial self-reorganization."

Although temporal patterns of ecosystem processes (e.g., ecological succession, responses to disturbance) have long served as a cornerstone of ecological research, considerable current interest in characterizing spatial heterogeneity in terrestrial ecosystems has arisen from an awareness of the intimate relationship between spatial heterogeneity of soil resources and maintenance of plant species diversity $[5,6]$. For example, working on limestone pavements of southern Ontario, Canada, Lundholm and Larson [7] found that, among $1440.18 \mathrm{~m}^{2}$ plots, peaks in species richness were most closely correlated with maximally heterogeneous plots. Hutchings et al. [8] suggested that the mechanism for such relationships arises from the alteration of interspecific competition brought about by spatial heterogeneity in soil resources. Significant responses of plant diversity to soil resource heterogeneity have been observed in studies that 
span virtually all spatial scales, from the plot (e.g., 1- $\mathrm{m}^{2}$ ) $[9,10]$ to the landscape $[11]$, and even on a global scale [12].

Indeed, although it has long been the bane of designs for field experiments [13], spatial heterogeneity is increasingly being considered an important, integral facet of terrestrial ecosystems $[14,15]$. The cycling of nutrients, particularly nitrogen $(\mathrm{N})$, in soils of terrestrial ecosystems is controlled by processes, such as microbial activity and plant nutrient dynamics, that often are quite spatially heterogeneous [1619]. Relatively undisturbed terrestrial ecosystems typically display a high degree of spatial heterogeneity, with spatially discrete areas of high $\mathrm{N}$ mineralization rates in soils. These have been referred to as "islands of fertility" by Schlesinger et al. [17] and as "hot spots" by McClain et al. [14]. Other sources of heterogeneity of $\mathrm{N}$ in watersheds include the dispersion pattern within populations of different tree species [20], spatial variability in hydrology [21], interspecific variation in fine root structure and $\mathrm{N}$ content of trees, and the patchiness associated with snow and soil freezing events [22]. Many of these factors not only can vary over successional time but can also exhibit distinct seasonal patterns.

Such a plant-driven scenario in the temporal and spatial heterogeneity of $\mathrm{N}$ dynamics is consistent with the challenge made by Schimel and Bennett [23] to the classic paradigm of controls on $\mathrm{N}$ cycling in terrestrial ecosystems, which generally considers plants to be consistently poor competitors with microbes for available N. Accordingly, this longheld paradigm essentially relegates plants to a passive role in $\mathrm{N}$ cycling of terrestrial ecosystems and taking up largely only the available $\mathrm{N}$ not utilized to fulfill microbial demand. By contrast, Schimel and Bennett [23] consider plants as active drivers in soil $\mathrm{N}$ processing, including creating and maintaining microsites for $\mathrm{N}$ dynamics, thus directly contributing to a degree of spatial heterogeneity that does indeed vary temporally.

Among the body of work published from the Fernow Watershed Acidification Study (WAS) at Fernow Experimental Forest, West Virginia, are several studies that have reported a high degree of spatial heterogeneity in $\mathrm{N}$ dynamics in the long-term reference watershed-WS4 [24]. Peterjohn et al. [25] and Christ et al. [26] suggested that spatial patterns of N processing within WS4 may be controlled in large part by variation in species composition of the overstory, with areas of high rates associated with sugar maple and low rates associated with oaks. Gilliam et al. [27] found that watershed-scale patterns of $\mathrm{N}$ processing were even more highly correlated with species composition of the herb layer than with overstory canopy composition.

Also as part of the WAS, Gilliam et al. [27] reported the effects of experimental additions of $\mathrm{N}$ to an entire watershed (WS3) on several indices of $\mathrm{N}$ availability, including in situ net N mineralization/nitrification, from 1993 to 1995. Whereas most of these indices (e.g., extractable $\mathrm{NO}_{3}{ }^{-}$ pools) were significantly higher on the treatment WS3 than on the control WS4, not all (e.g., net $\mathrm{N}$ mineralization) varied significantly between experimental watersheds. By contrast, virtually all indices of $\mathrm{N}$ availability displayed lower spatial heterogeneity on WS3, suggesting that additions of
$\mathrm{N}$ decreased spatial heterogeneity in $\mathrm{N}$ availability at the watershed scale.

The primary objective of this paper is to examine longterm patterns of stream $\mathrm{NO}_{3}{ }^{-}$in control and treatment watersheds at FEF in the context of temporal changes in spatial heterogeneity of soil $\mathrm{N}$ processing. As an indicator of soil $\mathrm{N}$ processing we use concentrations of $\mathrm{NO}_{3}{ }^{-}$in soil water, a parameter that generally correlates well with other measures of soil $\mathrm{N}$ processing, such as net nitrification and extractable $\mathrm{N}$ pools [28]. We tested the following hypotheses: (1) changes in stream $\mathrm{NO}_{3}{ }^{-}$for both untreated and $\mathrm{N}$ treated watersheds will follow recent observations of decline in stream $\mathrm{NO}_{3}{ }^{-}$at various sites in the eastern United States, and (2) experimental additions of $\mathrm{N}$ will decrease spatial heterogeneity in soil $\mathrm{N}$ processing at the watershed scale in a central Appalachian hardwood forest.

\section{Methods}

2.1. Study Site. This study was conducted at the Fernow Experimental Forest, occupying $\sim 1900$ ha of the Allegheny Mountain section of the unglaciated Allegheny Plateau in Tucker County, West Virginia $\left(39^{\circ} 03^{\prime} \mathrm{N}, 79^{\circ} 49^{\prime} \mathrm{W}\right)$. Annual precipitation for this region is approximately $1430 \mathrm{~mm}$, with amounts being generally higher during the growing season and with increasing elevation [29]. Soils of the study watersheds are coarse-textured Inceptisols (loamy-skeletal, mixed mesic Typic Dystrochrept) of the Berks and Calvin series, sandy loams derived from sandstone [30].

Samples were collected from two watersheds. WS4 currently supports a mixed-aged hardwood stand last cut between 1904 and 1911; this watershed served as the untreated control. WS3 supports an even-age hardwood stand last cut in 1969, wherein $\sim 90 \%$ of tree basal area was removed, except for a 3 ha shade strip left along the stream channel; this served as the treatment watershed, receiving additions of $\left(\mathrm{NH}_{4}\right)_{2} \mathrm{SO}_{4}$. Beginning in 1989, WS3 has received three aerial applications of $\left(\mathrm{NH}_{4}\right)_{2} \mathrm{SO}_{4} \mathrm{yr}^{-1}: 9 \mathrm{~kg} \mathrm{Nha}^{-1}$ in the spring, $17 \mathrm{~kg} \mathrm{Nha}^{-1}$ in the summer, and $9 \mathrm{~kg} \mathrm{Nha}^{-1}$ in late fall, for a total of

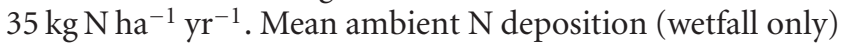
at FEF is $\sim 10 \mathrm{~kg} \mathrm{Nha}^{-1} \mathrm{yr}^{-1}$ [29]; dry deposition of $\mathrm{N}$ is $\sim 2 \mathrm{~kg} \mathrm{Nha}^{-1} \mathrm{yr}^{-1}$ [31].

Tree species were generally similar on these watersheds, with the primary difference being one of dominance. Early successional species, such as black birch (Betula lenta L.), black cherry (Prunus serotina Ehrh.), and yellow poplar (Liriodendron tulipifera L.) were dominant on WS3, whereas latesuccessional species, such as sugar maple (Acer saccharum Marshall) and northern red oak (Q. rubra L.) were dominant on WS4. Dominant herbaceous layer species included violets (Viola spp.), blackberry (Rubus spp.), stinging nettle (Laportea canadensis (L.) Wedd.), and several ferns [32].

2.2. Field Sampling and Analyses. One year prior to the initiation of $\mathrm{N}$ treatments on WS3 in 1989, 15 sample areas were established on each of WS3 and WS4 (Figure 1), following criteria detailed in Adams et al. [24]. Briefly, these locations were selected to represent the full range of 


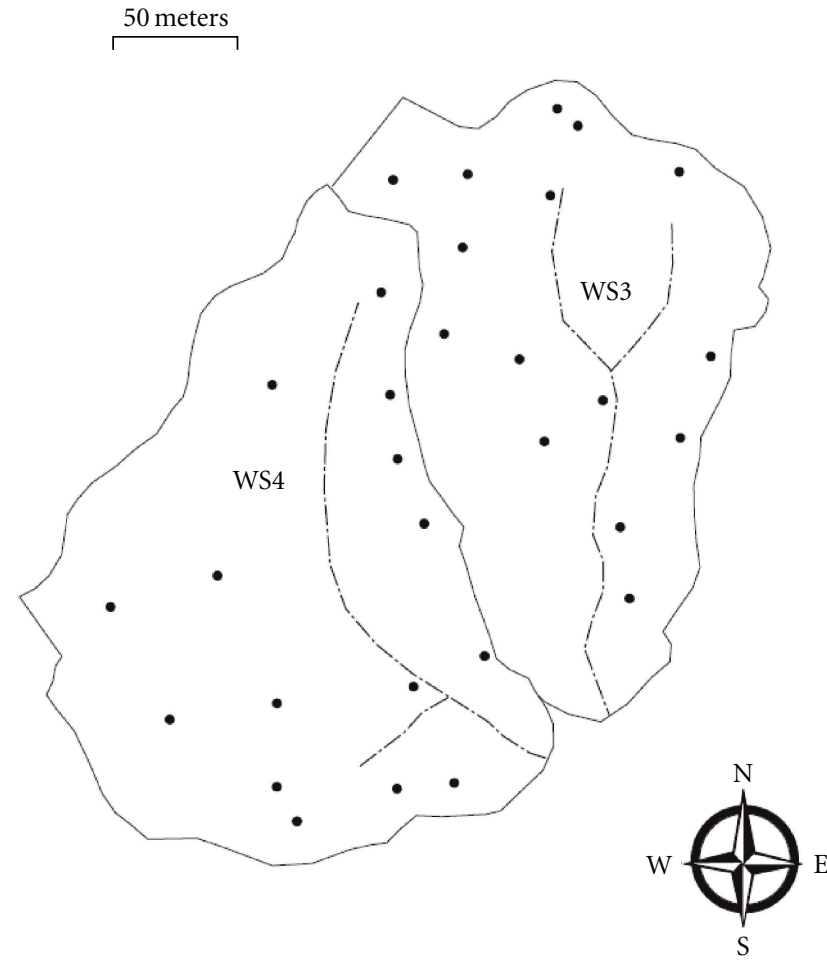

Figure 1: Map of study watersheds at Fernow Experimental Forest, West Virginia; each point on map represents a sample area including lysimeters used in this study. WS4 is the control watershed; WS3 is the treatment watershed, receiving $35 \mathrm{~kg} \mathrm{~N} \mathrm{ha}^{-1} \mathrm{yr}^{-1}$ as $\left(\mathrm{NH}_{4}\right)_{2} \mathrm{SO}_{4}$.

elevations and slope aspects of these watersheds. A zerotension lysimeter was installed at each sample area at each of two soil horizons: A (mean depth $13 \mathrm{~cm}$ ) and B (mean depth $79 \mathrm{~cm}$ ). Beginning January 1989 and currently on-going, soil water samples are taken on an approximately monthly basis when soil moisture is sufficient to produce samples. Stream water is similarly sampled on an on-going basis and is done in a variety of ways [33]. For this paper, stream water was grab-sampled weekly from 1984 through 2004 by field personnel at the Timber and Watershed Laboratory, Parsons, West Virginia. Further details for sampling and analysis can be found in Adams et al. [34] and Edwards et al. [33].

Stream samples were analyzed for $\mathrm{NO}_{3}{ }^{-}$with ion chromatography using a Dionex Model 10 IC until 2 November 1987. Since this date, all water samples, including stream and soil solution, have been analyzed for $\mathrm{NO}_{3}{ }^{-}$with a Dionex 400i HPLC [35].

2.3. Data Analysis. Annual concentrations of $\mathrm{NO}_{3}{ }^{-}$in stream water and soil solution were calculated as volumeweighted means [36]. The reporting period for stream data was from 1983 to 2004, whereas the period for soil water was 1989 to 2006.

Relationships between measured variables for both watersheds were assessed with linear regression, including stream $\mathrm{NO}_{3}{ }^{-}$concentrations versus time, stream versus soil water $\mathrm{NO}_{3}{ }^{-}$concentrations, soil water $\mathrm{NO}_{3}{ }^{-}$concentrations versus time, and coefficient of variation $(\mathrm{CV})$ versus mean

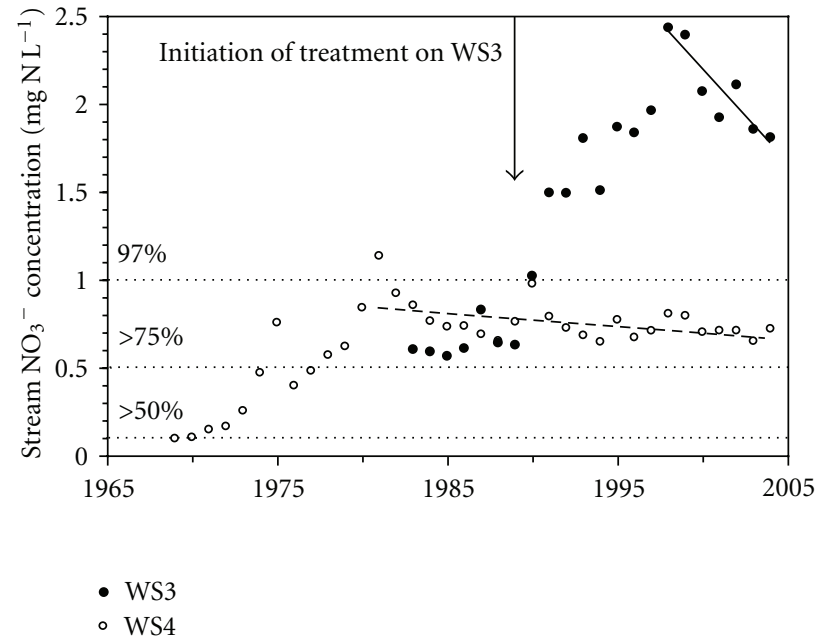

FIgURE 2: Mean annual stream water $\mathrm{NO}_{3}{ }^{-}$for WS3 (treatment: solid symbols) and WS4 (control: open symbols) at Fernow Experimental Forest, West Virginia. Arrow indicates initiation of $\mathrm{N}$ treatments on WS3. Horizontal dashed lines represent thresholds based on The State of the Nation's Ecosystems (see text). Heavy dashed line represents correlation between mean annual stream water $\mathrm{NO}_{3}{ }^{-}$and time from 1981 to 2004 for WS4 $(r=-0.51$, $P<.05)$; solid line represents relationship from 1998 to 2004 for WS3 $(r=-0.90, P<.01)$.

annual soil water $\mathrm{NO}_{3}{ }^{-}$concentration. Temporal patterns of soil water $\mathrm{NO}_{3}{ }^{-}$concentrations and associated $\mathrm{CV}$ were assessed with second-order polynomial functions.

We quantified spatial heterogeneity on the watershed scale by calculating the coefficient of variation $(\mathrm{CV})$ for each watershed and year. Use of $\mathrm{CV}$ has considerable precedence in the ecological literature for studies that assess spatial heterogeneity, including those such as ours that use permanent plots. Guo et al. [37] used CV to examine temporal changes in spatial variability among permanent plots of soil moisture in a slash pine (Pinus elliottii Engelm.) forest over a 2.5-year period. In their review that defined and quantified spatial heterogeneity, Li and Reynolds [38] referred to $\mathrm{CV}$ as a measure of the magnitude of variance in spatial data.

\section{Results and Discussion}

For watersheds with contrasting stand age and history, WS3 and WS4 have displayed surprising similarity in general longterm patterns of stream $\mathrm{NO}_{3}{ }^{-}$concentrations (Figure 2). The pattern for stream $\mathrm{NO}_{3}{ }^{-}$on N-treated WS3 was as follows over the nearly 20 years of the WAS: (1) lack of rapid, initial response to the $\mathrm{N}$ treatment begun in 1989, (2) increase in stream $\mathrm{NO}_{3}{ }^{-}$to a maximum in 1998 following this lag period, and (3) significant decline since 1998 (Figure 2). Although receiving no experimental manipulations of any kind, WS4 had a similar trend for stream $\mathrm{NO}_{3}{ }^{-}$as did WS3, but over a longer time period (Figure 2). A highly significant linear increase $(r=0.79, P<.01)$ in streamwater $\mathrm{NO}_{3}{ }^{-}$was reported by Peterjohn et al. [39] for WS4 from 1969 to 1990. 
Since the maximum annual concentration in 1981, however, $\mathrm{NO}_{3}{ }^{-}$has declined significantly $(r=-0.51, P<.05)$ to the present time.

The similarity in temporal patterns of stream $\mathrm{NO}_{3}{ }^{-}$ between these two watersheds is notable for two reasons. First, they support forests of sharply contrasting stand ages, with WS4 being typical of mature second-growth stands of this region [40] and WS3 being in an aggrading phase for most deciduous forest types [41]. Second, throughout the period since 1981 WS4 has received a cumulative total of just under $300 \mathrm{~kg} \mathrm{~N}$ via ambient atmospheric deposition (based on long-term means of annual $\mathrm{N}$ deposition), yet basal area of trees on WS4 has increased only minimally during this period; similarly, WS3 received a cumulative total of $245 \mathrm{~kg} \mathrm{Nha}^{-1}$ during the period of 1998 to the present as part of the WAS (see Methods) and yet there were actually decreases in growth rates for some tree species [42].

Certainly, temporal patterns for WS3 and WS4 at FEF are consistent with studies of hardwood forests of the northeastern USA that report recent declines in stream $\mathrm{NO}_{3}{ }^{-}$ concentrations [43-45]. Martin et al. [43] reported this pattern after resampling streams within the Bowl Research Natural Area in New Hampshire, finding decreases in stream $\mathrm{NO}_{3}{ }^{-}$over a 20 -year period beginning in the mid 1970s. Goodale et al. [44] found similar declines when they resampled most of the streams throughout the New England region that were initially sampled and reported by Vitousek and Reiners [46], suggesting that interannual variation in climate and its effects on biotic retention of $\mathrm{N}$ was the most likely mechanism, a conclusion challenged by Huntington [47].

Goodale et al. [48] further suggested that increases in dissolved organic carbon (DOC), which can facilitate net immobilization of mineral $\mathrm{N}$, might provide the most plausible mechanism for regional declines in stream $\mathrm{NO}_{3}{ }^{-}$. Dittman et al. [45] examined this phenomenon for Hubbard Brook Experimental Forest using a 12-year sampling period. They concluded that hydrologic flow paths exert an influence on stream $\mathrm{N}$ concentrations that can override both biotic and abiotic mechanisms of $\mathrm{N}$ retention.

Such a wide-spread occurrence of temporal declines in stream $\mathrm{NO}_{3}{ }^{-}$of relatively mature and undisturbed forests challenges predictions of traditional successional theory of nutrient cycling, as originally articulated by Odum [49] and further developed by Vitousek and Reiners [46]. Briefly, this theory recognizes that young, aggrading forest ecosystems should conserve $\mathrm{NO}_{3}{ }^{-}$because demand for available $\mathrm{N}$ by rapidly growing vegetation would exceed supply by atmospheric inputs and $\mathrm{N}$ mineralization. As these forests mature, net primary productivity (NPP) would decline and relative demand for $\mathrm{N}$ would attenuate proportionally, resulting in increases in loss of $\mathrm{N}$ via $\mathrm{NO}_{3}{ }^{-}$in streams. However, the synoptic scale of the observed decline of stream $\mathrm{NO}_{3}{ }^{-}$ suggests that processes other than those associated with stand age-related change in NPP may be more important than once thought.

At FEF, the <40-year-old stand on WS3 would be considered to be in an aggrading phase by most forest models (e.g., [41]) and, indeed, there was an initial positive growth response to the initiation of the $\mathrm{N}$ treatment [50]. However, current growth rates of some of the dominant tree species (e.g., P. serotina, L. tulipifera, and A. rubrum) on WS3 have decreased by as much as 50\% [42] and have done so at a time when stream $\mathrm{NO}_{3}{ }^{-}$is also declining, indicating that patterns of decline in stream $\mathrm{NO}_{3}{ }^{-}$are not the result of increased uptake by rapidly growing trees of an aggrading ecosystem.

It is further notable that the reference watershed at FEF (WS4) has been cited as one of the better examples of an $\mathrm{N}$-saturated watershed in North America [39, 51, 52]. To put our results in the context of stream $\mathrm{NO}_{3}{ }^{-}$ throughout the United States, we compare data for WS4 to those from the Heinz Center for Science, Economics and the Environment that, as part of The State of the Nation's Ecosystems, summarized stream $\mathrm{NO}_{3}{ }^{-}$data from the United States Geological Survey National Water Quality Assessment. They found that as of 1998, 97\% of forest streams in the United States had $\mathrm{NO}_{3}{ }^{-}$concentration less than $1 \mathrm{mg} \mathrm{N} \mathrm{L}^{-1}$, $>75 \%$ had concentrations less than $0.5 \mathrm{mg} \mathrm{N} \mathrm{L}^{-1}$, and $>50 \%$ had concentrations less than $0.1 \mathrm{mg} \mathrm{N} \mathrm{L}^{-1}$ [53]. Thus, over the period 1969 to 1981, the stream draining WS4 increased from a level typical of over half the forested streams in the USA to one found in only $\sim 3 \%$ of forested streams (Figure 4).

\section{Alternative Hypotheses for Temporal Declines in Stream $\mathrm{NO}_{3}{ }^{-}$}

In addition to mechanisms proposed by earlier studies (e.g., $[44,45,47,48,54]$ to explain temporal declines in stream $\mathrm{NO}_{3}{ }^{-}$that appear to be occurring on a synoptic scale in eastern USA and even in parts of Europe [55], we suggest that these temporal patterns can also be a function of spatial variability in soil $\mathrm{N}$ processing and that the degree of this spatial heterogeneity can change over time. In this section, we discuss long-term patterns of stream $\mathrm{NO}_{3}{ }^{-}$in the context of temporal variability in spatial heterogeneity of soil water $\mathrm{NO}_{3}{ }^{-}$. Finally, we discuss two processes-microbial population dynamics and decomposition - as potential mechanisms to relate temporal and spatial pattern. These processes share two characteristics: (1) they are sensitive to increases in $\mathrm{N}$ availability and (2) they potentially vary both temporally and spatially in watersheds of eastern deciduous forests.

4.1. Spatial Heterogeneity in Soil Water $\mathrm{NO}_{3}{ }^{-}$. For FEF during the period 1989 to 2004, annual mean concentrations of stream $\mathrm{NO}_{3}{ }^{-}$were significantly correlated with those of soil water $\mathrm{NO}_{3}{ }^{-}$on both WS3 $(r=0.70, P<.05)$ and WS4 $(r=0.60, P<.05)$ (Figure 3$)$. This correlation is also apparent in similarities in long-term temporal patterns between stream and soil water $\mathrm{NO}_{3}{ }^{-}$for both watersheds. For WS4, this was a significant decline in stream and soil water $\mathrm{NO}_{3}{ }^{-}$from the period of 1988 to the present (Figure 4(a)). For WS3, there was an initial lack of response to the $\mathrm{N}$ treatment, followed by an increase of stream $\mathrm{NO}_{3}{ }^{-}$ to a maximum concentration in 2000 and subsequent decline (Figure 4(b)). 


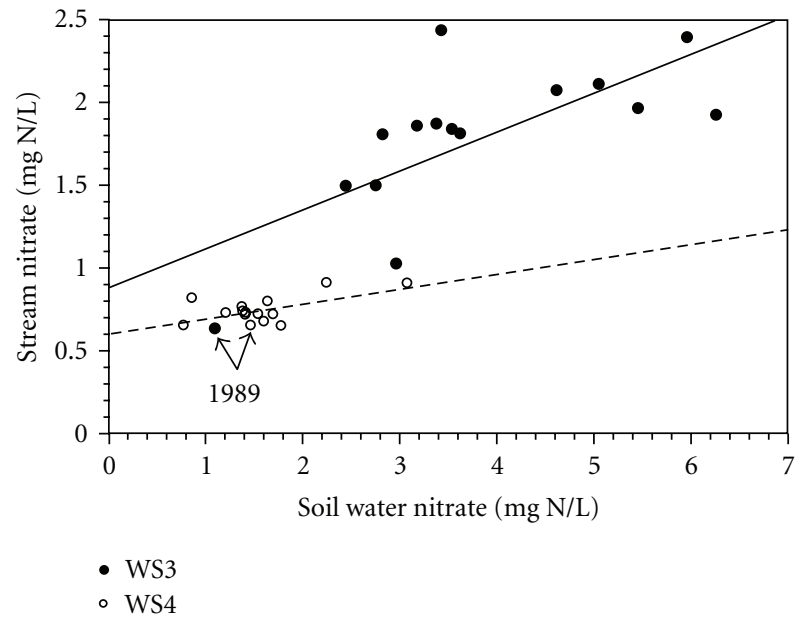

FIgURE 3: Mean annual stream water $\mathrm{NO}_{3}{ }^{-}$versus mean annual soil water $\mathrm{NO}_{3}{ }^{-}$concentrations for WS3 (treatment: solid symbols) and WS4 (control: open symbols) at Fernow Experimental Forest, West Virginia. Each point represents mean soil water $\mathrm{NO}_{3}{ }^{-}$for $\mathrm{A}$ and $\mathrm{B}$ horizon lysimeters for a given year. Line represents linear correlations: WS3: $r=0.70, P<.003$; WS4: $r=0.60, P<.05$.

Furthermore, data for soil water $\mathrm{NO}_{3}{ }^{-}$on the study watersheds over the period 1989 to 2006 at FEF suggest that spatial heterogeneity can decrease with increasing $\mathrm{N}$ supply, consistent with a prediction of the $\mathrm{N}$ homogeneity hypothesis $[56,57]$ that increases in $\mathrm{N}$ deposition decrease spatial heterogeneity of $\mathrm{N}$ processing. In the one-year pretreatment period, mean annual concentrations of soil water $\mathrm{NO}_{3}{ }^{-}$were nearly identical, and spatial heterogeneity (CV) was similar between watersheds (Figure 5). Heterogeneity of soil water $\mathrm{NO}_{3}{ }^{-}$on the untreated WS4 remained consistently high, with nine years exhibiting CVs $>100 \%$, or essentially half of the years for the sample period; soil water $\mathrm{NO}_{3}{ }^{-}$at WS4 remained consistently low (Figure 4(a)). By contrast, WS3 exhibited a maximum heterogeneity (CV) of $\sim 105 \%$ for the one year prior to treatment, followed by a significant decrease toward a minimum of $\sim 60 \%$ by $2000-2001$ (Figure $4(\mathrm{~b})$ ). During this time, mean annual concentrations of soil water $\mathrm{NO}_{3}{ }^{-}$displayed a notable response to the $\mathrm{N}$ treatments on WS3, increasing nearly 5 -fold from $1.3 \mathrm{mg} \mathrm{NO}_{3}{ }^{-} \mathrm{N} \mathrm{L}^{-1}$ in the pretreatment year (1989) to a maximum of $6.4 \mathrm{mg} \mathrm{NO}_{3}{ }^{-}$$\mathrm{N} \mathrm{L}^{-1}$ in 2001 (Figure 4(b)).

Linear correlation suggests a relationship between concentration of soil water $\mathrm{NO}_{3}{ }^{-}$and spatial heterogeneity on the watershed scale at FEF. CV of soil water $\mathrm{NO}_{3}{ }^{-}$and mean concentration of soil water $\mathrm{NO}_{3}{ }^{-}$were negatively $(P<$ $.05, r=-0.60)$ correlated for WS3, but not for WS4 for the sample period, 1989-2006 (Figure 5). The pretreatment year (1989) values for CV and, in particular, mean soil water $\mathrm{NO}_{3}{ }^{-}$were similar between watersheds: $125.9 \%$ and $1.21 \mathrm{mg} \mathrm{NO}_{3}{ }^{-}-\mathrm{N} \mathrm{L}^{-1}$, respectively, for WS4 and $102.5 \%$ and $1.34 \mathrm{mg} \mathrm{NO}_{3}{ }^{-}-\mathrm{N} \mathrm{L}^{-1}$ for WS3. On average, this varied little over the study period on WS4, with a centroid mean of 105.0 $\%$ and $1.54 \mathrm{mg} \mathrm{NO}_{3}{ }^{-}-\mathrm{N} \mathrm{L}^{-1}$; by contrast, the centroid mean for WS3 was $71.6 \%$ and $3.85 \mathrm{mg} \mathrm{NO}_{3}{ }^{-}-\mathrm{N} \mathrm{L}^{-1}$ (Figure 5).
Although the mechanisms whereby added $\mathrm{N}$ decreases spatial heterogeneity of processing of soil $\mathrm{N}$ are difficult to elucidate at the watershed scale, studies at much finer spatial scales than those of a watershed (e.g., $1-10 \mathrm{~m}^{2}$ ) have demonstrated that maintenance of high spatial heterogeneity in soil nutrients can arise from so-called "islands of fertility" $[10,17,58,59]$. These are essentially discreet patches of high soil nutrient availability brought about by the clumped distribution of populations of terrestrial plant species which provide inputs of organic matter through litterfall, turnover of fine roots, and species-specific variation in the $\mathrm{N}$ content of throughfall and stemflow [60]. We suggest that excess $\mathrm{N}$ mediated decreases in spatial heterogeneity of soil $\mathrm{N}$ arise from a "filling in" of the matrix within which these patches naturally occur. That is, inputs of $\mathrm{N}$ from atmospheric deposition increase $\mathrm{N}$ availability within the low- $\mathrm{N}$ matrix to approach that within the patches of high fertility. Indeed, recent studies have demonstrated the active role of plants in influencing soil $\mathrm{N}$ dynamics, which represents a departure from a long-held paradigm of $\mathrm{N}$ biogeochemistry [23].

4.2. N-Mediated Change in Size, Composition, and Activity of Microbial Communities. Soil microbial communities are extremely complex and diverse, certainly much more so than the plant communities with which they are associated [61]. They are also sensitive and responsive to changes in environmental conditions, such as temperature, and availability of essential resources, such as moisture and nutrients. Although rarely, if ever studied at the scale of a watershed ecosystem, several studies have shown that both microbial biomass and composition change drastically with experimental additions of N [62]. Indeed, Schmidt et al. [63] found that although soil and microbial $\mathrm{N}$ pools were higher in $\mathrm{N}$-fertilized plots, both microbial activity and biomass were lower following $\mathrm{N}$ fertilization, with negative effects being more profound in the growing season.

Marschner et al. [64] examined the long-term effects of several forms of organic and inorganic $\mathrm{N}$ on structure and function of microbial communities of soils in Germany following 31 years of treatment. They found that bacterial communities, but not eukaryotic microbial communities, were particularly sensitive to $\mathrm{N}$ treatments. They also found profound changes in microbial composition in response to $\mathrm{N}$ treatments. More recently, Treseder [65] performed a metaanalysis of 82 published field studies of the effects of $\mathrm{N}$ additions on microbial biomass, finding no significant effects of ecosystem type, form of $\mathrm{N}$ fertilizer, level of ambient $\mathrm{N}$ deposition, or even microbial biomass methodology. However, she estimated that excess $\mathrm{N}$ reduced microbial biomass by $15 \%$ across all studies.

As part of the Chronic Nitrogen Amendment Study at Harvard Forest, Frey et al. [66] reported reductions in active fungal, but not bacterial, biomass in response to both low $\left(50 \mathrm{~kg} \mathrm{ha}^{-1} \mathrm{yr}^{-1}\right)$ and high $\left(150 \mathrm{~kg} \mathrm{ha}^{-1} \mathrm{yr}^{-1}\right)$ levels of $\mathrm{N}$ additions. $\mathrm{N}$ treatments also decreased the diversity of the ectomycorrhizal fungal community. Working on the same plots, Compton et al. [67] also found that chronic $\mathrm{N}$ additions altered the soil microbial community; results suggested that $\mathrm{N}$ treatments inhibited $\mathrm{N}_{2}$-fixing populations. 


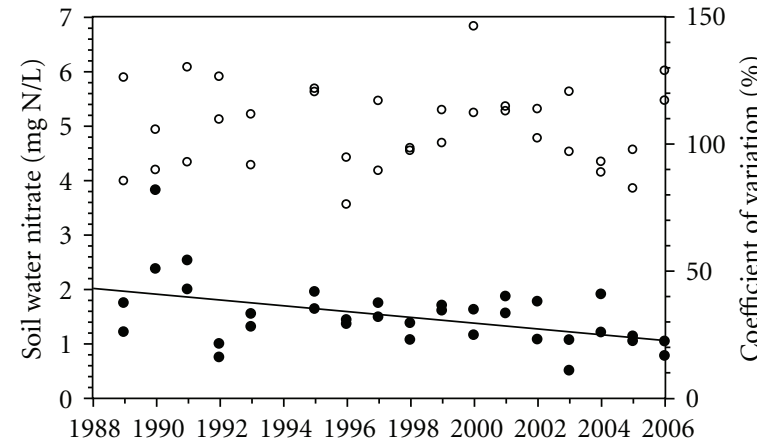

(a)

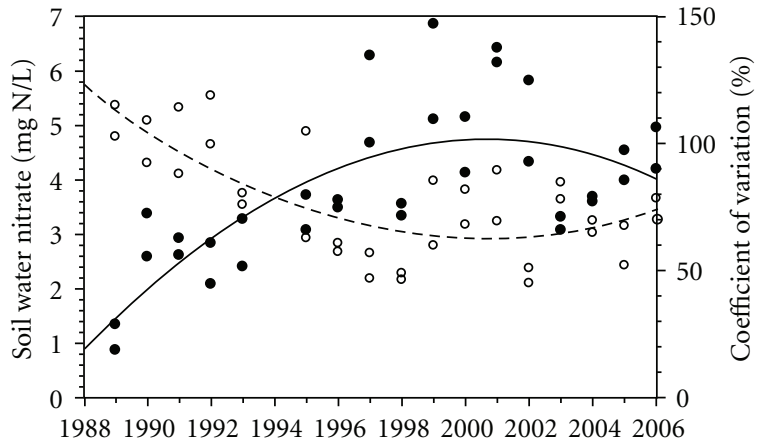

(b)

FIGURE 4: Annual mean soil water $\mathrm{NO}_{3}{ }^{-}$concentration (solid circles) and corresponding coefficients of variation (CV) (open circles) from 1989 (pretreatment year) to 2006 for (A) WS4 (control): solid line is soil water $\mathrm{NO}_{3}{ }^{-}$versus year- $y=107.8-0.053 x, r^{2}=0.22, P<.05-$ and (B) WS3 (treatment): dashed curve is CV versus year and represents the following 2nd-order polynomial: $y=1504363-1503 x+0.36 x^{2}$, $r^{2}=0.53, P<.01$; solid curve is soil water $\mathrm{NO}_{3}{ }^{-}$versus year and represents the following 2nd-order polynomial: $y=-97016+97.0 x-$ $0.024 x^{2}, r^{2}=0.53, P<.01$.

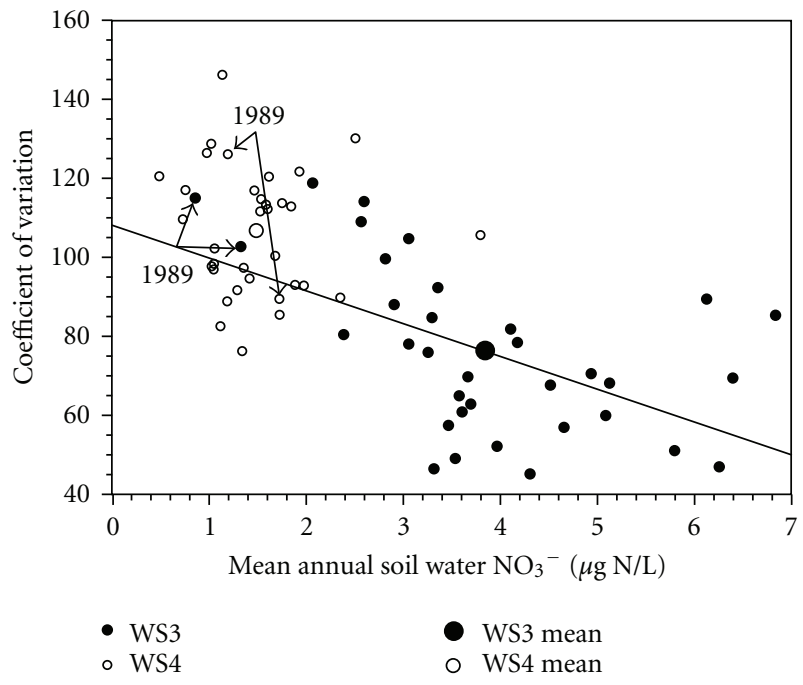

Figure 5: Coefficients of variation (CV) versus annual mean soil water $\mathrm{NO}_{3}{ }^{-}$concentration from 1989 (pre-treatment year) to 2006 for WS3 (treatment) and WS4 (control). Points in graph are combinations of soil water $\mathrm{NO}_{3}{ }^{-}$for $\mathrm{A}$ and $\mathrm{B}$ horizon lysimeters. Shown also are the combined means of $\mathrm{CV}$ and concentration (i.e., centroids) and the location of the pretreatment year (1989) for WS3 and WS4. Line represents linear correlation $(r=-0.60, P<.05)$ for WS3 only.

Increases in $\mathrm{N}$ supply to forests clearly have the potential to alter the microbial communities of forest soils and do so at the watershed scale. Working at another forested site at FEF, Wallenstein et al. [68] found that $\mathrm{N}$ amendments did not alter denitrifier communities, indicating that observed decreases in stream $\mathrm{NO}_{3}{ }^{-}$are not likely the result of increased denitrification. We suggest that excess $\mathrm{N}$-mediated shifts in microbial communities are toward those that simply process $\mathrm{N}$ at much lower rates (i.e., lower net $\mathrm{N}$ mineralization and nitrification) rather than those that affect immobilization. Data from on-going in situ incubations at
FEF indicate that rates of net nitrification on WS3 declined by $50 \%$ from 1995 to 2002 and by a further $80 \%$ from 2002 to 2005; declines over the same time intervals for WS4 were 52\% and $67 \%$, respectively (Gilliam and Peterjohn, unpublished data).

4.3. N-Mediated Decreases in Decomposition. Decomposition rates of organic material in forests are determined largely by litter quality, which is partly defined by $\mathrm{N}$ content, with higher rates usually accompanying higher $\mathrm{N}$ content [69]. Thus, it may be expected that higher inputs of $\mathrm{N}$ to forests might lead to higher rates of decomposition. To the contrary, several recent studies have shown that increased $\mathrm{N}$ not only can fail to stimulate rates of decomposition [70] but can often inhibit decomposition [71-74]. A metaanalysis of 24 studies on the effects of $\mathrm{N}$ additions on decomposition rates found widely varying results [75]: decomposition was inhibited at low and high rates of $\mathrm{N}$ addition ( $<75$ and $>125 \mathrm{~kg} \mathrm{Nha}^{-1} \mathrm{yr}^{-1}$, resp.), and was stimulated at intermediate rates $\left(75-125 \mathrm{~kg} \mathrm{~N} \mathrm{ha}^{-1} \mathrm{yr}^{-1}\right)$. On our watersheds at FEF, Adams and Angradi [76] found that $\mathrm{N}$ additions to WS3 significantly decrease litter decomposition rates of ecologically important species of central hardwood forests, for example, yellow poplar, black cherry, and black birch.

\section{Conclusions}

Temporal patterns of mean $\mathrm{NO}_{3}{ }^{-}$concentrations in soil solution support previous findings for soil $\mathrm{N}$ dynamics (i.e., $\mathrm{N}$ mineralization and nitrification) at FEF that increases in supply of $\mathrm{N}$ decrease spatial heterogeneity in $\mathrm{N}$ processing. There was a significant, negative relationship between soil water $\mathrm{NO}_{3}{ }^{-}$and spatial heterogeneity on the N-treated WS3. The decline in soil water $\mathrm{NO}_{3}{ }^{-}$on WS3 was consistent with the pattern of decline in stream water $\mathrm{NO}_{3}{ }^{-}$that has occurred since 1998. A similar decline has been observed for untreated WS4 since 1981 and for several forest streams over the past 20 years in the eastern United States. Although 
it has been suggested that successional change in ecosystem demand for $\mathrm{N}$ may explain the declines in soil and stream water $\mathrm{NO}_{3}{ }^{-}$concentrations, similar temporal trends for two watersheds at different successional stages at FEF indicate that this proposed mechanism is not operating at our site. On the other hand, experimental additions of $\mathrm{N}$ have been demonstrated to alter soil microbial communities, including the balance between autotrophic and heterotrophic production of $\mathrm{NO}_{3}{ }^{-}$. In addition, $\mathrm{N}$ additions have been shown to decrease rates of decomposition of forest litter in several studies. Thus, based on evidence in the literature, we suggest that such effects may explain, at least in part, these observed declines. Such patterns challenge long-held theories of successional change in the biogeochemistry of forest ecosystems and open up new areas for further research.

\section{Acknowledgments}

The authors wish to thank the following field and laboratory personnel at the Timber and Watershed Laboratory, Parsons, West Virginia, for their efforts collecting and analyzing soil water and stream samples: Doug Owens, Layne Godwin, Frank Long, and John Pearce. They also thank Frederica Wood for data management skills and for providing summarized data for the 17-year period and thank Mary Arthur for reading an earlier version of the paper and for comments that greatly improved it. Finally, they thank anonymous reviewers for numerous comments and suggestions for improvements on an earlier version.

\section{References}

[1] H. C. Cowles, "The ecological relations of the vegetation on the sand dunes of Lake Michigan," Botanical Gazette, vol. 27, pp. 95-117, 167-202, 281-308, 361-391, 1899.

[2] L. H. Yang and S. Naeem, "The ecology of resource pulses," Ecology, vol. 89, no. 3, pp. 619-620, 2008.

[3] W. B. Anderson, D. A. Wait, and P. Stapp, "Resources from another place and time: responses to pulses in a spatially subsidized system," Ecology, vol. 89, no. 3, pp. 660-670, 2008.

[4] M. Rietkerk and J. van de Koppel, "Regular pattern formation in real ecosystems," Trends in Ecology and Evolution, vol. 23, no. 3, pp. 169-175, 2008.

[5] R. E. Ricklefs, "Environmental heterogeneity and plant species diversity," American Naturalist, vol. 111, pp. 376-381, 1977.

[6] S. W. Beatty, "Habitat heterogeneity and maintenance of species in understory communities," in The Herbaceous Layer in Forests of Eastern North America, F. S. Gilliam and M. R. Roberts, Eds., Oxford University Press, New York, NY, USA, 2003.

[7] J. T. Lundholm and D. W. Larson, "Relationships between spatial environmental heterogeneity and plant species diversity on a limestone pavement," Ecography, vol. 26, no. 6, pp. 715-722, 2003.

[8] M. J. Hutchings, E. A. John, and D. K. Wijesinghe, "Toward understanding the consequences of soil heterogeneity for plant populations and communities," Ecology, vol. 84, no. 9, pp. 2322-2334, 2003.

[9] M. Palmer, "Spatial scale and patterns of species-environmental relationships in hardwood forests of the North Carolina piedmont," Coenoses, vol. 5, pp. 79-87, 1990.
[10] D. A. Dick and F. S. Gilliam, "Spatial heterogeneity and dependence of soils and herbaceous plant communities in adjacent seasonal wetland and pasture sites," Wetlands, vol. 27, no. 4, pp. 951-963, 2007.

[11] A. Dufour, F. Gadallah, H. H. Wagner, A. Guisan, and A. Buttler, "Plant species richness and environmental heterogeneity in a mountain landscape: effects of variability and spatial configuration," Ecography, vol. 29, no. 4, pp. 573-584, 2006.

[12] H. Kreft and W. Jetz, "Global patterns and determinants of vascular plant diversity," Proceedings of the National Academy of Sciences of the United States of America, vol. 104, no. 14, pp. 5925-5930, 2007.

[13] P. Dutilleul, "Spatial heterogeneity and the design of ecological field experiments," Ecology, vol. 74, no. 6, pp. 1646-1658, 1993.

[14] M. E. McClain, E. W. Boyer, C. L. Dent et al., "Biogeochemical hot spots and hot moments at the interface of terrestrial and aquatic ecosystems," Ecosystems, vol. 6, no. 4, pp. 301-312, 2003.

[15] G. M. Lovett, C. G. Jones, M. G. Turner, and K. C. Weathers, Eds., Ecosystem Function in Heterogeneous Landscapes, Springer, New York, NY, USA, 2005.

[16] T. B. Parkin, "Spatial variability of microbial processes in soil-a review," Journal of Environmental Quality, vol. 22, no. 3, pp. 409-417, 1993.

[17] W. H. Schlesinger, J. A. Raikks, A. E. Hartley, and A. F. Cross, "On the spatial pattern of soil nutrients in desert ecosystems," Ecology, vol. 77, no. 2, pp. 364-374, 1996.

[18] T. L. Thompson, E. Zaady, P. Huancheng, T. B. Wilson, and D. A. Martens, "Soil C and $\mathrm{N}$ pools in patchy shrublands of the Negev and Chihuahuan Deserts," Soil Biology and Biochemistry, vol. 38, no. 7, pp. 1943-1955, 2006.

[19] D. C. Housman, C. M. Yeager, B. J. Darby et al., "Heterogeneity of soil nutrients and subsurface biota in a dryland ecosystem," Soil Biology and Biochemistry, vol. 39, no. 8, pp. 2138-2149, 2007.

[20] S. Getzin, T. Wiegand, K. Wiegand, and F. He, "Heterogeneity influences spatial patterns and demographics in forest stands," Journal of Ecology, vol. 96, no. 4, pp. 807-820, 2008.

[21] B. Michalzik, K. Kalbitz, J. H. Park, S. Solinger, and E. Matzner, "Fluxes and concentrations of dissolved organic carbon and nitrogen-a synthesis for temperate forests," Biogeochemistry, vol. 52, no. 2, pp. 173-205, 2001.

[22] R. D. Fitzhugh, C. T. Driscoll, P. M. Groffman, G. L. Tierney, T. J. Fahey, and J. P. Hardy, "Soil freezing and the acid-base chemistry of soil solutions in a Northern Hardwood Forest," Soil Science Society of America Journal, vol. 67, no. 6, pp. 18971908, 2003.

[23] J. P. Schimel and J. Bennett, "Nitrogen mineralization: challenges of a changing paradigm," Ecology, vol. 85, no. 3, pp. 591-602, 2004.

[24] M. B. Adams, D. R. DeWalle, and J. L. Hom, Eds., The Fernow Watershed Acidification Study, Springer, New York, NY, USA, 2006.

[25] W. T. Peterjohn, C. J. Foster, M. J. Christ, and M. B. Adams, "Patterns of nitrogen availability within a forested watershed exhibiting symptoms of nitrogen saturation," Forest Ecology and Management, vol. 119, no. 1-3, pp. 247-257, 1999.

[26] M. J. Christ, W. T. Peterjohn, J. R. Cumming, and M. B. Adams, "Nitrification potentials and landscape, soil and vegetation characteristics in two Central Appalachian watersheds differing in $\mathrm{NO}_{3}^{-}$export," Forest Ecology and Management, vol. 159, no. 3, pp. 145-158, 2002. 
[27] F. S. Gilliam, B. M. Yurish, and M. B. Adams, "Temporal and spatial variation of nitrogen transformations in nitrogensaturated soils of a central appalachian hardwood forest," Canadian Journal of Forest Research, vol. 31, no. 10, pp. 1768 1785, 2001.

[28] B. Matejek, M. Kohlpaintner, R. Gasche, C. Huber, M. Dannenmann, and H. Papen, "The small-scale pattern of seepage water nitrate concentration in an $\mathrm{N}$ saturated spruce forest is regulated by net $\mathrm{N}$ mineralization in the organic layer," Plant and Soil, vol. 310, no. 1-2, pp. 167-179, 2008.

[29] F. S. Gilliam and M. B. Adams, "Wetfall deposition and precipitation chemistry for a central Appalachian forest," Journal of the Air and Waste Management Association, vol. 46, no. 10, pp. 978-984, 1996.

[30] F. S. Gilliam, N. L. Lyttle, A. Thomas, and M. B. Adams, "Soil variability along a nitrogen mineralization and nitrification gradient in a nitrogen-saturated hardwood forest," Soil Science Society of America Journal, vol. 69, no. 1, pp. 247-256, 2005.

[31] R. E. Baumgardner, T. F. Lavery, C. M. Rogers, and S. S. Isil, "Estimates of the atmospheric deposition of sulfur and nitrogen species: Clean Air Status and Trends Network, 19902000," Environmental Science and Technology, vol. 36, no. 12, pp. 2614-2629, 2002.

[32] F. S. Gilliam, A. W. Hockenberry, and M. B. Adams, "Effects of atmospheric nitrogen deposition on the herbaceous layer of a central Appalachian hardwood forest," Journal of the Torrey Botanical Society, vol. 133, no. 2, pp. 240-254, 2006.

[33] P. J. Edwards, K. W. J. Williard, F. Wood, and W. E. Sharpe, "Soil water and stream water chemical responses," in The Fernow Watershed Acidification Study, M. B. Adams, D. R. DeWalle, and J. L. Hom, Eds., Springer, New York, NY, USA, 2006.

[34] M. B. Adams, T. R. Angradi, and J. N. Kochenderfer, "Stream water and soil solution responses to 5 years of nitrogen and sulfur additions at the Fernow Experimental Forest, West Virginia," Forest Ecology and Management, vol. 95, no. 1, pp. 79-91, 1997.

[35] M. B. Adams, J. N. Kochenderfer, F. Wood, T. R. Angradi, and P. Edwards, "Forty years of hydrometeorological data from the Fernow Experiment Forest, West Virginia. Gen," Tech. Rep. NE-184, U. S. Department of Agriculture, Forest Service, Northeastern Forest Experiment Station, Radnor, Pa, USA, 1994.

[36] J. H. Zar, Biostatistical Analysis, Prentice Hall, Upper Saddle River, NJ, USA, 4th edition, 1999.

[37] D. Guo, P. Mou, R. H. Jones, and R. J. Mitchell, “Temporal changes in spatial patterns of soil moisture following disturbance: an experimental approach," Journal of Ecology, vol. 90, no. 2, pp. 338-347, 2002.

[38] H. Li and J. F. Reynolds, "On definition and quantification of heterogeneity," Oikos, vol. 73, no. 2, pp. 280-284, 1995.

[39] W. T. Peterjohn, M. B. Adams, and F. S. Gilliam, "Symptoms of nitrogen saturation in two central Appalachian hardwood forest ecosystems," Biogeochemistry, vol. 35, no. 3, pp. 507522, 1996.

[40] G. G. Mcgee, D. J. Leopold, and R. D. Nyland, "Structural characteristics of old-growth, maturing, and partially cut northern hardwood forests," Ecological Applications, vol. 9, no. 4, pp. 1316-1329, 1999.

[41] C. D. Oliver and B. C. Larson, Forest Stand Dynamics, John Wiley \& Sons, New York, NY, USA, Update edition, 1996.
[42] J. D. May, S. B. Burdette, F. S. Gilliam, and M. B. Adams, "Interspecific divergence in foliar nutrient dynamics and stem growth in a temperate forest in response to chronic nitrogen inputs," Canadian Journal of Forest Research, vol. 35, no. 5, pp. 1023-1030, 2005.

[43] C. W. Martin, C. T. Driscoll, and T. J. Fahey, "Changes in streamwater chemistry after 20 years from forested watersheds in New Hampshire, U.S.A," Canadian Journal of Forest Research, vol. 30, no. 8, pp. 1206-1213, 2000.

[44] C. L. Goodale, J. D. Aber, and P. M. Vitousek, "An unexpected nitrate decline in New Hampshire streams," Ecosystems, vol. 6, no. 1, pp. 75-86, 2003.

[45] J. A. Dittman, C. T. Driscoll, P. M. Groffman, and T. J. Fahey, "Dynamics of nitrogen and dissolved organic carbon at the Hubbard Brook Experimental Forest," Ecology, vol. 88, no. 5, pp. 1153-1166, 2007.

[46] P. M. Vitousek and W. A. Reiners, "Ecosystem succession and nutrient retention: a hypothesis," BioScience, vol. 25, pp. 376381, 1975.

[47] T. G. Huntington, "Can nitrogen sequestration explain the unexpected nitrate decline in New Hampshire streams?" Ecosystems, vol. 8, no. 3, pp. 331-333, 2005.

[48] C. L. Goodale, J. D. Aber, P. M. Vitousek, and W. H. McDowell, "Long-term decreases in stream nitrate: successional causes unlikely; possible links to DOC?” Ecosystems, vol. 8, no. 3, pp. 334-337, 2005.

[49] E. P. Odum, “The strategy of ecosystem development," Science, vol. 164, no. 3877, pp. 262-270, 1969.

[50] D. R. DeWalle, J. N. Kochenderfer, M. B. Adams et al., "Vegetation and acidification," in The Fernow Watershed Acidification Study, M. B. Adams, D. R. DeWalle, and J. L. Hom, Eds., Springer, Dordrecht, The Netherlands, 2006.

[51] J. L. Stoddard, "Long-term changes in watershed retention of nitrogen: its causes and aquatic consequences ," in Environmental Chemistry of Lakes and Reservoirs, L. A. Baker, Ed., Advances in Chemistry Series, no. 237, American Chemical Society, Washington, DC, USA, 1994.

[52] S. E. Gress, T. D. Nichols, C. C. Northcraft, and W. T. Peterjohn, "Nutrient limitation in soils exhibiting differing nitrogen availabilities: what lies beyond nitrogen saturation?" Ecology, vol. 88, no. 1, pp. 119-130, 2007.

[53] The H. John Heinz III Center for Science, Economics and the Environment, The State of the Nation's Ecosystems: Measuring the Lands, Waters, and Living Resources of the United States, Cambridge University Press, Cambridge, UK, 2002.

[54] J. D. Aber and C. T. Driscoll, "Effects of land use, climate variation, and $\mathrm{N}$ deposition on $\mathrm{N}$ cycling and $\mathrm{C}$ storage in northern hardwood forests," Global Biogeochemical Cycles, vol. 11, no. 4, pp. 639-648, 1997.

[55] M. Rogora, "Synchronous trends in $\mathrm{N}^{-\mathrm{NO}_{3}^{-}}$export from Nsaturated river catchments in relation to climate," Biogeochemistry, vol. 86, no. 3, pp. 251-268, 2007.

[56] F. S. Gilliam, "Response of the herbaceous layer of forest ecosystems to excess nitrogen deposition," Journal of Ecology, vol. 94, no. 6, pp. 1176-1191, 2006.

[57] F. S. Gilliam, R. L. McCulley, and J. A. Nelson, "Spatial variability in soil microbial communities in a nitrogensaturated hardwood forest watershed," Soil Science Society of America Journal, vol. 75, no. 1, pp. 280-286, 2011.

[58] H. Stoyan, H. De-Polli, S. Böhm, G. P. Robertson, and E. A. Paul, "Spatial heterogeneity of soil respiration and related properties at the plant scale," Plant and Soil, vol. 222, no. 1-2, pp. 203-214, 2000. 
[59] F. S. Gilliam and D. A. Dick, "Spatial heterogeneity of soil nutrients and plant species in herb-dominated communities of contrasting land use," Plant Ecology, vol. 209, no. 1, pp. 8394, 2010.

[60] R. H. Crockford, D. P. Richardson, and R. Sageman, "Chemistry of rainfall, throughfall and stemflow in a eucalypt forest and a pine plantation in south-eastern Australia: 3. Stemflow and total inputs," Hydrological Processes, vol. 10, no. 1, pp. 25 42, 1996.

[61] K. M. Carney and P. A. Matson, "Plant communities, soil microorganisms, and soil carbon cycling: does altering the world belowground matter to ecosystem functioning?" Ecosystems, vol. 8, no. 8, pp. 928-940, 2005.

[62] D. Gilbert, C. Amblard, G. Bourdier, and A. J. Francez, "Short-term effect of nitrogen enrichment on the microbial communities of a peatland," Hydrobiologia, vol. 373-374, pp. 111-119, 1998.

[63] S. K. Schmidt, D. A. Lipson, R. E. Ley, M. C. Fisk, and A. E. West, "Impacts of chronic nitrogen additions vary seasonally and by microbial functional group in tundra soils," Biogeochemistry, vol. 69, no. 1, pp. 1-17, 2004.

[64] P. Marschner, E. Kandeler, and B. Marschner, "Structure and function of the soil microbial community in a long-term fertilizer experiment," Soil Biology and Biochemistry, vol. 35, no. 3, pp. 453-461, 2003.

[65] K. K. Treseder, "Nitrogen additions and microbial biomass: a meta-analysis of ecosystem studies," Ecology Letters, vol. 11, no. 10, pp. 1111-1120, 2008.

[66] S. D. Frey, M. Knorr, J. L. Parrent, and R. T. Simpson, “Chronic nitrogen enrichment affects the structure and function of the soil microbial community in temperate hardwood and pine forests," Forest Ecology and Management, vol. 196, no. 1, pp. 159-171, 2004.

[67] J. E. Compton, L. S. Watrud, L. A. Porteous, and S. DeGrood, "Response of soil microbial biomass and community composition to chronic nitrogen additions at Harvard forest," Forest Ecology and Management, vol. 196, no. 1, pp. 143-158, 2004.

[68] M. D. Wallenstein, W. T. Peterjohn, and W. H. Schlesinger, "N fertilization effects on denitrification and $\mathrm{N}$ cycling in an aggrading forest," Ecological Applications, vol. 16, no. 6, pp. 2168-2176, 2006.

[69] J. M. Melillo, J. D. Aber, and J. F. Muratore, "Nitrogen and lignin control of hardwood leaf litter decomposition dynamics," Ecology, vol. 63, no. 3, pp. 621-626, 1982.

[70] S. E. Hobbie, "Contrasting effects of substrate and fertilizer nitrogen on the early stages of litter decomposition," Ecosystems, vol. 8, no. 6, pp. 644-656, 2005.

[71] M. M. Carreiro, R. L. Sinsabaugh, D. A. Repert, and D. F. Parkhurst, "Microbial enzyme shifts explain litter decay responses to simulated nitrogen deposition," Ecology, vol. 81, no. 9, pp. 2359-2365, 2000.

[72] K. Michel and E. Matzner, "Nitrogen content of forest floor Oa layers affects carbon pathways and nitrogen mineralization," Soil Biology and Biochemistry, vol. 34, no. 11, pp. 1807-1813, 2002.

[73] J. M. Craine, C. Morrow, and N. Fierer, "Microbial nitrogen limitation increases decomposition," Ecology, vol. 88, no. 8, pp. 2105-2113, 2007.

[74] H. Fang, J. Mo, S. Peng, Z. Li, and H. Wang, "Cumulative effects of nitrogen additions on litter decomposition in three tropical forests in southern China," Plant and Soil, vol. 297, no. 1-2, pp. 233-242, 2007.
[75] M. Knorr, S. D. Frey, and P. S. Curtis, "Nitrogen additions and litter decomposition: a meta-analysis," Ecology, vol. 86, no. 12, pp. 3252-3257, 2005.

[76] M. B. Adams and T. R. Angradi, "Decomposition and nutrient dynamics of hardwood leaf litter in the Fernow Whole-Watershed Acidification Experiment," Forest Ecology and Management, vol. 83, no. 1-2, pp. 61-69, 1996. 

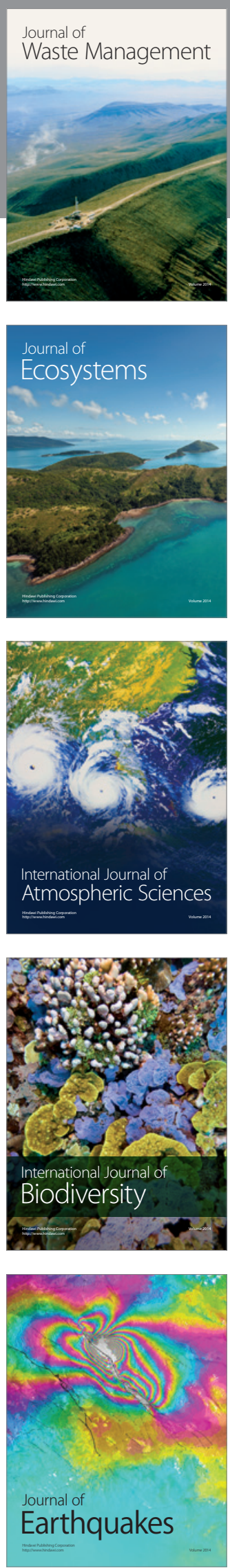
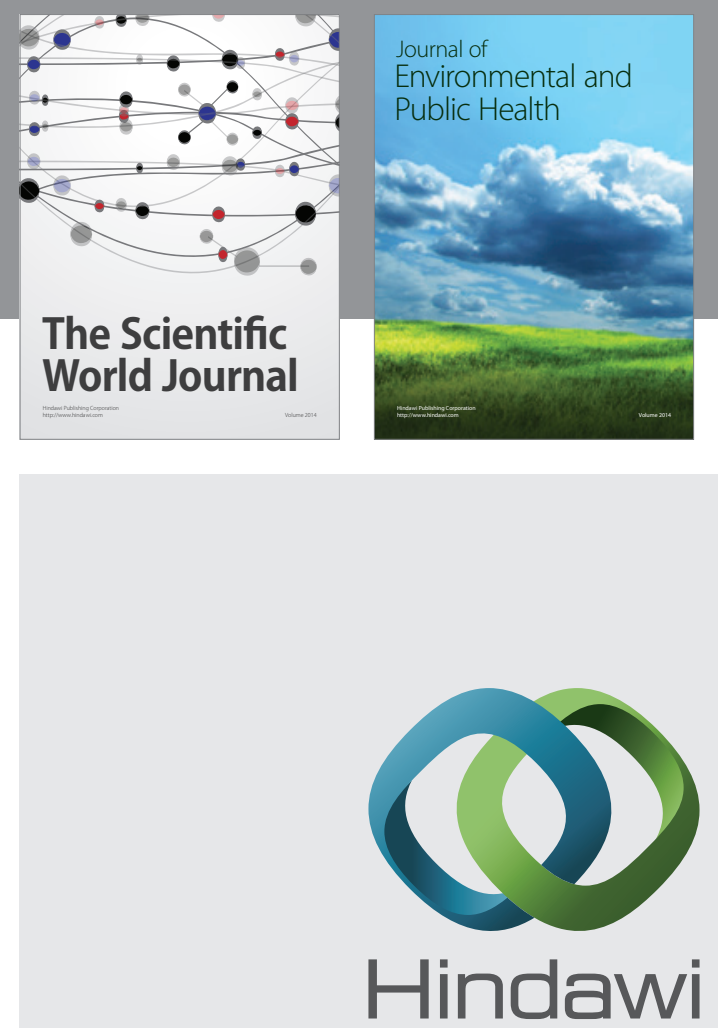

Submit your manuscripts at

http://www.hindawi.com
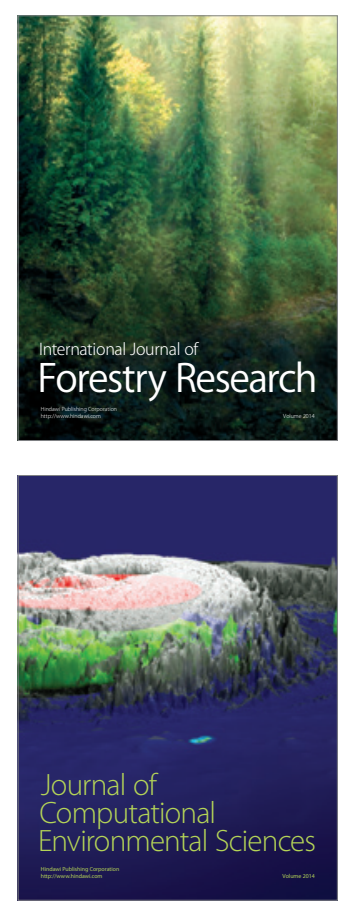
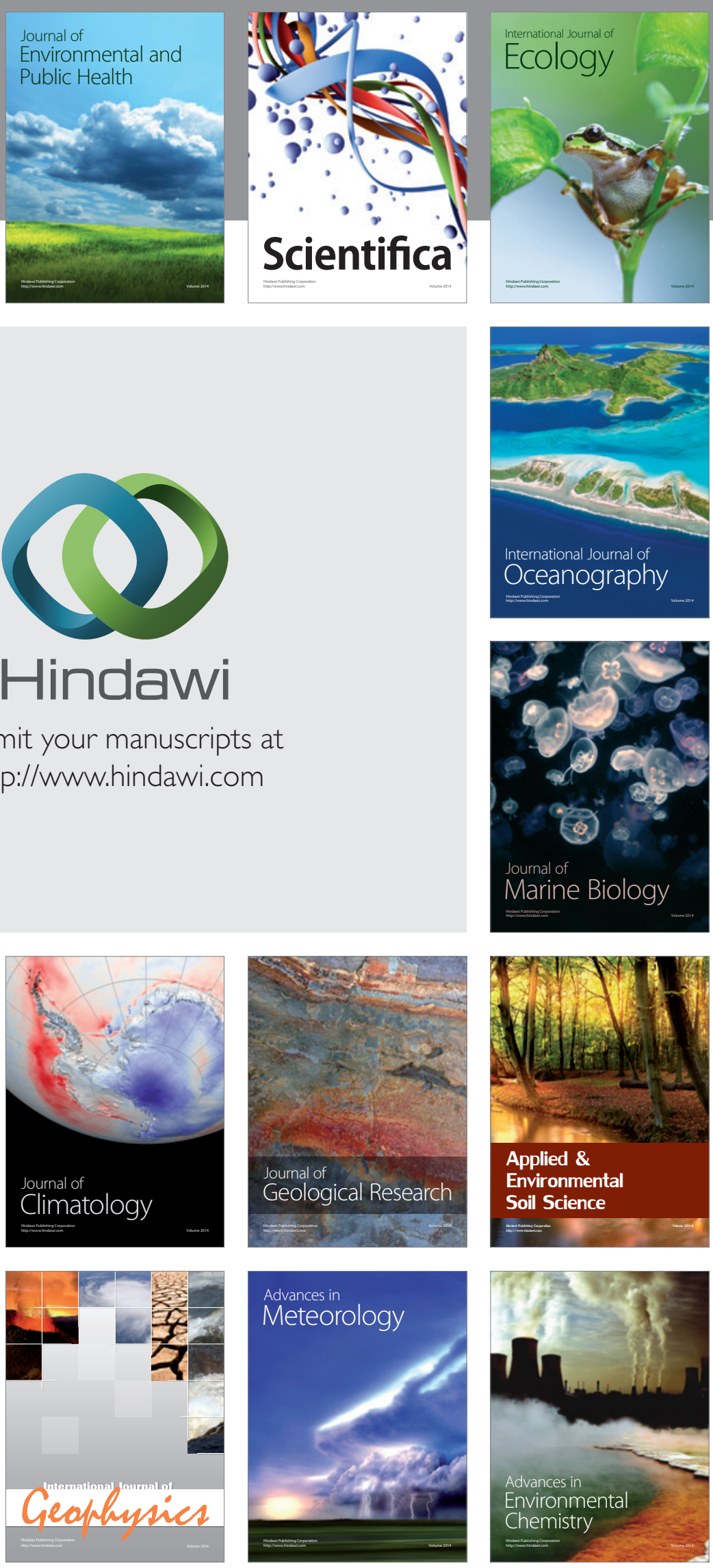